\title{
Determination of the Development Potential of Urban Territories on the Basis of Integrated Assessment of the Social-Ecomomic Zoning by the Example of the City of Kazan
}

RubtzovV.A.

Kazan Federal University, Institute of Management, Economics and Finance, Kazan, 420008, Russia

Delabarr O.A.

Kazan Federal University, Institute of Management, Economics and Finance, Kazan, 420008, Russia

Gabdrakhmanov N.K.

Kazan Federal University, Institute of Management, Economics and Finance, Kazan, 420008, Russia

Email:nz9nz@rambler.ru

Pratchenko O.V.

Kazan Federal University, Institute of Language, 420008, Kazan, Russia

\section{Doi:10.5901/mjss.2015.v6n3p681}

\section{Abstract}

State city-planning policy and management should provide favorable conditions of human life and society through, in particular, integrated programs (projects) of development that determine the problems and priorities of the area under study. Functional zoning scheme is the starting point of design and planning decisions. In this work the potential of urban areas is considered on the basis of a comprehensive assessment of the city of Kazan.

Keywords: planning, zoning, assessment, price index, city, area, residential complex, Kazan.

\section{Introduction}

State city-planning policy and management should provide favorable conditions of human life and society through, in particular, integrated programs (projects) of development that determine the problems and priorities of the area under study. Functional zoning scheme is the starting point of design and planning decisions [1]. Schemes of integrated assessment of the territory that allow to highlight areas characterized by relatively homogeneous condition of indicators and similar conditions of their development are the basis to refer the particular area to the particular functional zone [2,3]. Special regime of use of the area connected with the detailed account of intra-facility differences and with the differentiated approach to the objects themselves, is assigned to each of the functional zones. Thus, functional zoning of the area can be defined as a method of modeling that allows to achieve the most efficient, equilibrium state of all subsystems and maximum efficiency of the system in whole.

Zoning is a multi-component, multi-layered problem which is solved in several stages:

- the first stage: a sample of parametric characteristics that best reflect the development of the process and the collection of source information is drawn;

- the second stage: private zoning of the city site by the most important social-economic indicators that determine the level of its development by parameters is carried out;

- the last stage: integral zoning by the degree of development of territorial units on the basis of a collective estimate of parametric characteristics, determination of the development potential and growth points of the urban environment is carried out.

In our study, a residential complex is the smallest indivisible primary unit of the management structure, which is a territorial community of residential buildings and facilities of different economic orientation located in residential areas, is 
used as the operating-territorial unit. Within the city limits of Kazan 51 apartment complexes were identified.

\section{Method}

The method of principal components which belongs to the group of methods and models of the factor analysis allowed to receive the score of each of the proposed indicators, which formed the basis of area zoning. The method of "Wroclaw autonomy" was used as a method of zoning [4,5]. Formation of zones and subzones that reflect changes in the value of populated areas, became the result of the work. Thus, on the territory of Kazan the following zones were identified:

- zones of reduced cost of the ground in relation to average in the city, where subzones of catastrophic, problematic and acceptable reduction of the price index;

- $\quad$ areas with minor deviations from average city values are areas with a price index close to one;

- zones of the increase of value of land areas are zones where there is improvement of quality characteristics of residential areas; subzones of average, high and unacceptable increase of the price index.

Detailed analysis of socio-economic factors (by the method of principal components) which affect the degree of attractiveness of various parts of the city, was also held to highlight the zones with different relative value of residential areas. The following factors were referred to them: environmental status, influence of industrial complex, development of road transport network, condition of populated areas.

Today the assessment of the ecological state of the city [6] becomes very important, especially in terms of luxury housing. The more the state of the area corresponds to modern environmental requirements, the higher the value of housing property is on it. In the analysis of the ecological state of residential complexes special attention is paid to excess of emissions into the atmosphere by industrial enterprises and maximum permissible concentration of hazardous substances in the water basin of the city, soil pollution, noise, vibration, electromagnetic and radiation background, the public landscape planting. On the territory of the city the Sovietsky district received the highest score in the evaluation of the ecological state of the administrative districts, as far as remote, well-landscaped areas are within its boundaries. But the presence of hazardous industry did not allow it to leave far behind the Novo-Savinovsky district, on the territory of which there are almost no any industrial enterprises, and there is the well-developed transport and road network. Only the Vakhitovskiy district which is at the intersection of the city's major highways and which is located on the windward side of the industrial areas of the Privolzhsky district, was in the group with the lowest estimate of the ecological state.

Within the residential areas of urban settlements in case of location of industrial enterprises it is necessary to provide sanitary-protection zones in which the following facilities should not be located: residential areas, kindergartens, schools, institutions of sport and recreation. The most favorable situation is in the Novo-Savinovsky district where the borders of sanitary-protection zones are not violated, due to the insignificance of the area occupied by industrial production. The lowest values of the indicators are in the Privolzhsky district, on the territory of which the industrial complex, partially formed in the pre-revolutionary period, when there was no any notion of sanitary-protection zones, is located.

When assessing the impact of transport infrastructure $[7,8]$ on the state of the residential area the following parameters were used as the main indicators for the analysis: density of the road and transport network of districts, quality of roads. Optimal development of road-transport network is in the Vakhitovsky district due to the very high density of transport routes. The Aviastroitelny and Sovetsky districts, on the territory of which there is a high percentage of individual buildings, the roads of the 3rd and 4th categories dominate, and the public transport network is less developed, have the lowest scores. In general, we can conclude that the city is not provided well enough by the network of roads, especially in the suburban areas; besides, it is necessary to increase the capacity of roads of the districts that occupy the transit location (the Moskovsky and the Novo-Savinovsky) [9,10,11,12].

When assessing the actually developed populated areas the following indicators were chosen: physical condition of the housing stock, its provision by water supply, sewerage, gas central heating, sanitation of the territory, facilities of education, health care and trade. Research showed that the best development of the residential area is in the Vakhitovsky district, where a high level of social and cultural services provided for population is combined with a high proportion of high-end and improved housing. The lowest values are in the Aviastroitelny district characterized by a high proportion of low-cost housing, a high percentage of depreciation of housing stock and utilities, with underdeveloped network of consumer service enterprises.

\section{Conclusion}

The zoning scheme of the territory of Kazan became the result of work (Fig. 1). A number of events were proposed on the 
basis of an integrated comprehensive assessment in order to reconcile the inconsistencies of development of the area within the administrative boundaries, followed by differentiation of residential complexes by the price index, and to identify prospects of their further development.

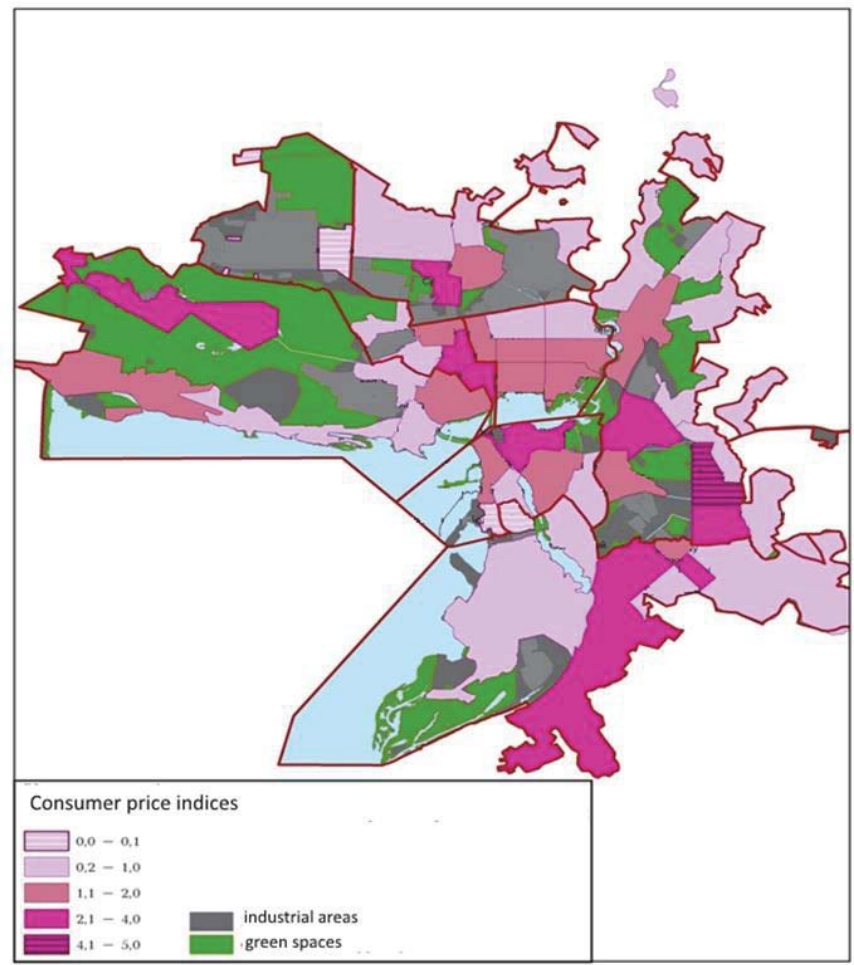

Fig.1. Change of price index in relation to average city values

It is obvious that in the citywide the residential area has rather ambiguous development and requires significant improvements. Change of the status of the half of non-prestigious districts into the city-average level is the primary task in order to change the quality of the urban environment. Besides, it is necessary to smooth down the indicators within the boundaries of administrative districts in order to reduce the level of differentiation of lands within them.

\section{References}

Gabdrakhmanov N.K., Rubtzov V.A., Shabalina S.A., Rozhko M.V.,. Kucheryavenko D.Z The role of territorial organization of cities in the touristic attraction of the region on the example of the Republic of Tatarstan // Life Science Journal 2014;11(11), Pages 451-455.

Denmukhametov, R.R., Zjablova, O.V., Shtanchaeva, M.R. Document Development factors of Kazan region recreation area // Life Science Journal 11 (11), 2014, pp. 317-320

Safiullin, L.N., Gafurov, I.R., Shaidullin, R.N., Safiullin, N.Z. Socio-economic development of the region and its historical and cultural heritage // Life Science Journal 11 (6 SPEC. ISSUE), 2014, pp. 400-404

Denmukhametov, R.R. and O.V. Zjablova,. Geodemographic situation in the Republic of Tatarstan. World Applied Sciences Journal. Volume 30, Issue 11, 2014, Pages 1684-1688.

Gabdrakhmanov N.K. and M.V. Rozhko Positioning of Volga Federal District Regions by Demographic Situation Index // World Applied Sciences Journal, Volume 30 Number 6, 2014. - Pages 792-795.

Bagautdinova, N.G., Safiullin, L.N., Badrtdinov, N.N. The role of consumer expenses in ensuring forward dynamics of the Russian economy // Mediterranean Journal of Social Sciences 5 (12), 2014, pp. 43-48

Gabdrakhmanov, N.K. and V.A. Rubtsov, 2014. Tourist and Recreational Positioning of Tatarstan Republic: Cluster Analysis. World Applied Sciences Journal, 30(Management, Economics, Technology \& Tourism): Pages 202-205.

Mingaleva, Z., Bunakov, O. Innovative ways of using the tourist potential as the basis of territories development // Life Science Journal. Volume 11, Issue 6 SPEC. ISSUE, 2014, Pages 315-317.

Gabdrakhmanov, N.K. and V.A. Rubtzov, 2014. Geodemographic Polarization Processes: Municipal Level (The Case of the Kukmorsky 
Municipal District of the Republic of Tatarstan). World Applied Sciences Journal, 30(10): Pages 1317-1320.

N.K. Gabdrakhmanov, V.A. Rubtsov. The Objects of Social Infrastructure in the Social Image of the Region Shaping // Procedia - Social and Behavioral Sciences 140 ( 2014 ) 419 - 421

Gabdrakhmanov N.K., Rozhko M.V., \& Kucheryavenko D.Z. Critical and uncritical regions, Advences in Applied Sciences [Online]. 2014, 02, pp 113-116.

Komarova, V.N., Zjablova, O.V., Denmukhametov, R.R. An infrastructure factor in regional competitiveness // Mediterranean Journal of Social Sciences, 5 (18 SPEC. ISSUE), 2014, pp. 355-360. 